\title{
Correction to: A Closer Look at the Role of Anti-CCP Antibodies in the Pathogenesis of Rheumatoid Arthritis Associated Interstitial Lung Disease and Bronchiectasis
}

Tanjila Khan · Ricardo J. José $\cdot$ Elisabetta A. Renzoni $\cdot$ Maria Mouyis

Published online: September 27, 2021

(C) The Author(s) 2021

Correction to: Rheumatol Ther

https://doi.org/10.1007/s40744-021-00362-4

In the original article published, the given name and the family name of the second author is interchanged. The correct name is Ricardo J. José.

The original article has been corrected.

\section{OPEN ACCESS}

This article is licensed under a Creative Commons Attribution-NonCommercial 4.0 International License, which permits any non-

The original article can be found online at https://doi. org/10.1007/s40744-021-00362-4.

T. Khan · R. J. José

Department of Respiratory Medicine, Royal

Brompton Hospital, London, UK

R. J. José

Centre for Inflammation and Tissue Repair, UCL

Respiratory, UCL, London, UK

E. A. Renzoni

Interstitial Lung Disease Unit, Royal Brompton Hospital, Margaret Turner Warwick Centre for Fibrosing Lung Disease, NHLI, Imperial College London, London, UK

\section{Mouyis ( $\square)$}

Department of Rheumatology, Luton and Dunstable University Hospital, Luton, UK e-mail: m.mouyis@nhs.net commercial use, sharing, adaptation, distribution and reproduction in any medium or format, as long as you give appropriate credit to the original author(s) and the source, provide a link to the Creative Commons licence, and indicate if changes were made. The images or other third party material in this article are included in the article's Creative Commons licence, unless indicated otherwise in a credit line to the material. If material is not included in the article's Creative Commons licence and your intended use is not permitted by statutory regulation or exceeds the permitted use, you will need to obtain permission directly from the copyright holder. To view a copy of this licence, visit http://creativecommons.org/licenses/by$\mathrm{nc} / 4.0 /$. 